\title{
Reviews and syntheses: Soil responses to manipulated precipitation changes - an assessment of meta-analyses
}

\author{
Akane O. Abbasi ${ }^{1}$, Alejandro Salazar ${ }^{2,3}$, Youmi $\mathrm{Oh}^{4}$, Sabine Reinsch ${ }^{5}$, Maria del Rosario Uribe ${ }^{1}$, Jianghanyang $\mathrm{Li}^{4}$, \\ Irfan Rashid $^{6}$, and Jeffrey S. Dukes ${ }^{1,2}$ \\ ${ }^{1}$ Department of Forestry and Natural Resources, Purdue University, West Lafayette, IN 47907, USA \\ ${ }^{2}$ Department of Biological Sciences, Purdue University, West Lafayette, IN 47907, USA \\ ${ }^{3}$ Programa de Ciencias Básicas de la Biodiversidad, Instituto de Investigación de Recursos Biológicos \\ Alexander von Humboldt, Bogotá, 110311, Colombia \\ ${ }^{4}$ Department of Earth, Atmospheric, and Planetary Sciences, Purdue University, West Lafayette, IN 47907, USA \\ ${ }^{5}$ UK Centre for Ecology \& Hydrology, Bangor, LL57 2UW, UK \\ ${ }^{6}$ Department of Botany, University of Kashmir, Srinagar, 190006, India
}

Correspondence: Akane O. Abbasi (aota@purdue.edu)

Received: 30 January 2020 - Discussion started: 11 February 2020

Revised: 13 June 2020 - Accepted: 25 June 2020 - Published: 29 July 2020

\begin{abstract}
In the face of ongoing and projected climatic changes, precipitation manipulation experiments (PMEs) have produced a wealth of data about the effects of precipitation changes on soils. In response, researchers have undertaken a number of synthetic efforts. Several meta-analyses have been conducted, each revealing new aspects of soil responses to precipitation changes. Here, we conducted a comparative analysis of the findings of 16 meta-analyses focused on the effects of precipitation changes on 42 soil response variables, covering a wide range of soil processes. We examine responses of individual variables as well as more integrative responses of carbon and nitrogen cycles. We find strong agreement among meta-analyses that belowground carbon and nitrogen cycling accelerate under increased precipitation and slow under decreased precipitation, while bacterial and fungal communities are relatively resistant to decreased precipitation. Much attention has been paid to fluxes and pools in carbon, nitrogen, and phosphorus cycles, such as gas emissions, soil carbon, soil phosphorus, extractable nitrogen ions, and biomass. The rates of processes underlying these variables (e.g., mineralization, fixation, and (de)nitrification) are less frequently covered in meta-analytic studies, with the major exception of respiration rates. Shifting scientific attention to these less broadly evaluated processes would deepen the current understanding of the effects of precipitation changes on soil and provide new insights. By jointly evaluating meta-
\end{abstract}

analyses focused on a wide range of variables, we provide here a holistic view of soil responses to changes in precipitation.

\section{Introduction}

Soil is an important component of terrestrial ecosystems through which carbon, nitrogen, phosphorus, and other elements cycle. Biological processes in soils, such as those driven by plant roots, microbes, and enzymes, regulate nutrient cycling, with direct impacts on aboveground plant and animal communities (Bardgett et al., 2008). Rates of biological activity in soils are largely determined by physical parameters, one of the most influential being soil moisture (Stark and Firestone, 1995; Brockett et al., 2012; Schimel, 2018). Historical observations have shown that annual precipitation has either increased or decreased significantly in many regions, and the intensity and frequency of precipitation extremes (heavy rainfalls and droughts) have likewise increased in many regions (Frei et al., 2006; Lenderink and van Meijgaard, 2008). These changes in precipitation patterns are projected to continue in the future, possibly at a faster rate (Bao et al., 2017).

The activity of plant roots, microorganisms, and enzymes is maximized at optimal soil water content, which is unique 
to each group of organisms, soil type, and ecosystem (Bouwman, 1998; Schimel, 2018). Water in soil functions as (1) a resource to promote metabolism of microbes and plants, (2) a solvent of nutrients, and (3) a transport medium to provide pathways to solutes and microorganisms (Schimel, 2018; Tecon and Or, 2017). In a water-limited environment, reduced belowground activities are common (Borken et al., 2006; Sardans and Peñuelas, 2005). The negative responses of soil processes to decreased precipitation are attributed to reduced metabolism of the organisms (Salazar-Villegas et al., 2016; Schimel et al., 2007), limited substrate availability or diffusivity (Manzoni et al., 2016), restricted mobility of the organisms (Manzoni et al., 2016), or a combination of these (Schimel, 2018). Increased precipitation, on the other hand, generally promotes processes by shifting the soil moisture level closer to the optimum (Zhang et al., 2013; Zhou et al., 2013). However, excess water in soil often results in lower biological activity due to the limitation of oxygen flow (Bouwman, 1998; Reinsch et al., 2017), while anaerobic processes such as methane production are greatly promoted (Le Mer and Roger, 2001).

Natural variation in precipitation provides opportunities to observe responses of belowground activities (e.g., Goldstein et al., 2000; Granier et al., 2007), but targeted studies of belowground responses are difficult. Controlled precipitation manipulation experiments offer the opportunity to specifically study ecosystem responses to changes in precipitation compared to naturally occurring fluctuations and have become common in recent decades (Beier et al., 2012; Borken et al., 2006; Knapp et al., 2017). Precipitation manipulation experiments (PMEs) involve constructing an experimental structure in the field, such as rainout shelters, curtains, and/or sprinklers, to simulate alternative precipitation patterns (Beier et al., 2012). These setups enable direct comparisons between a manipulated precipitation treatment and a control (ambient precipitation) in the same study system, while keeping other environmental conditions nearly identical. PMEs have been established across ecosystem types and characteristics (biome, ecosystem, soil type, and land type) and often use different methodological approaches (e.g., in terms of the magnitude and duration of the precipitation manipulation, size of the experiment, method of rain exclusion, and/or variables measured; Vicca et al., 2014).

A number of meta-analyses have assembled and synthesized large and diverse PME datasets (Blankinship et al., 2011; Canarini et al., 2017; Wu et al., 2011). The first to examine soil responses to precipitation changes was conducted by $\mathrm{Wu}$ et al. (2011), compiling 85 manipulation studies and presenting the changes in aboveground and belowground carbon dynamics. Since then, several additional meta-analyses have considered belowground responses to precipitation changes. As of April 2019, according to our search criteria (details below), a total of 16 meta-analyses in this area were published. These meta-analyses focused on different but complementary soil properties (e.g., soil $\mathrm{C}$ in
Zhou et al., 2016, or $\mathrm{N}$ in Yue et al., 2019). A combined analysis of these meta-analyses would provide a holistic view of the potential effects of projected precipitation changes on soil processes.

In this paper, we conduct a comparative analysis of 16 meta-analyses that have examined soil responses to manipulated (increased and decreased) precipitation in situ, encompassing 42 response variables including greenhouse gas exchanges, carbon and nitrogen dynamics, phosphorus content, microbial community, and enzyme activities. By collating the results of the published meta-analyses, we aimed to (1) provide a more holistic view of the effects of precipitation changes on soil composition and functioning, (2) discuss the potential underlying mechanisms of each response, and (3) identify knowledge gaps and propose future research directions. This study covers an unusually wide range of soil processes and examines the responses of individual variables as well as nutrient cycles.

\section{Review of meta-analyses}

\subsection{Meta-analysis collection}

We collected peer-reviewed meta-analyses focused on the effects of decreased and/or increased precipitation on soil variables. We collected meta-analyses that included only field studies where the magnitude of precipitation was manipulated. Some meta-analyses included both field and laboratory or greenhouse experiments, but we only analyzed field data in our comparisons. We used Google Scholar and Web of Science with the search terms "meta-analysis" AND "soil" AND ("respiration" $\mathrm{OR}$ " $\mathrm{CO}_{2}$ " $\mathrm{OR}$ "carbon" $\mathrm{OR}$ "nutrient" OR “nitro" OR "phosph" OR " $\mathrm{N}_{2} \mathrm{O}$ ” $\mathrm{OR}$ " $\mathrm{CH}_{4}$ ” $\mathrm{OR}$ “microb" OR "enzyme" OR "bacteria” OR "fungi”) AND ("altered precipitation" OR "drought" OR "decreased precipitation" OR “increased precipitation” OR “water addition” OR "water reduction"). We identified 16 meta-analyses (Table 1); 4 of them focused on decreased precipitation (DP), 1 of them on increased precipitation (IP), and 11 on both DP and IP. A total of 42 soil variables were covered, encompassing a wide range of soil characteristics such as soil greenhouse gas exchanges, soil carbon, nitrogen, phosphorous, microbial and bacterial communities, enzymes, and physical characteristics of soil (Table 2). Only meta-analyses written in English and published before April 2019 were included in our analysis. All of the meta-analyses except for Brzostek et al. (2012) collected observations globally, with a greater concentration of data in the United States (US), Europe, and China than in other parts of the world. The dataset of Brzostek et al. (2012) is US-only, yet their data cover a wide range of ecosystem types and biomes. 
Table 1. List of meta-analyses used in this study.

\begin{tabular}{ll}
\hline No. & Meta-analysis \\
\hline 1 & Blankinship et al. (2011) \\
2 & Brzostek et al. (2012) \\
3 & Canarini et al. (2017) \\
4 & He and Dijkstra (2014) \\
5 & Homyak et al. (2017) \\
6 & Liu et al. (2016) \\
7 & Ren et al. (2018) \\
8 & Ren et al. (2017) \\
9 & Wu et al. (2011) \\
10 & Xiao et al. (2018) \\
11 & Yan et al. (2018) \\
12 & Yuan et al. (2017) \\
13 & Yue et al. (2019) \\
14 & Yue et al. (2018) \\
15 & Zhou et al. (2016) \\
16 & Zhou et al. (2018) \\
\hline
\end{tabular}

\subsection{Effect sizes}

From each meta-analysis, we obtained the mean effect size of each soil variable. In this review, effect sizes are the natural $\log$ of response ratios $(\ln R R)$ defined as

$\ln \mathrm{RR}=\ln \left(\frac{X_{\mathrm{t}}}{X_{\mathrm{c}}}\right)$,

where $X_{\mathrm{t}}$ and $X_{\mathrm{c}}$ are the mean values of the treatment (DP or IP) and control, respectively, for each observation. Homyak et al. (2017) used Hedge's $d$ instead of Eq. (1) for $\mathrm{N}_{2} \mathrm{O}$ emissions and $\mathrm{N}$ supply due to the negativity of RR. Hedge's $d$ is defined as $J\left(X_{\mathrm{t}}-X_{\mathrm{c}}\right) / S$ where $S$ is the pooled standard deviation (SD) and $J$ is the correction of small sample bias (Homyak et al., 2017). Both ln RR and Hedge's $d$ are negative for inhibitory effects and positive for stimulatory effects (Brzostek et al., 2012; Homyak et al., 2017). All metaanalyses calculated mean effect sizes and $95 \%$ confidence intervals (CIs) with sample size or the inverse of the variance as the weighting function. The effect is considered significant when $95 \%$ CI does not overlap zero. Some metaanalyses applied additional weighting functions or normalized the measurements under different manipulation levels (Liu et al., 2016; Wu et al., 2011). We used these samplesize- or variance-weighted effect sizes when available. We obtained the values from the main texts or supplementary materials of the articles. If necessary, we used the digitizing software Plot Digitizer (Huwaldt and Steinhorst, 2015) to extract values from graphs. When only percent changes were reported, we converted to $\ln \mathrm{RR}$ as in Ren et al. (2017, 2018):

$\ln \mathrm{RR}=\ln \left(\frac{\% \text { change }}{100}+1\right)$.
Some $95 \%$ CIs were unavailable because points were not visible on graphs or because values of percent change below $-100 \%$ were not convertible using Eq. (2) (e.g., He and Dijkstra, 2014). We also obtained the sample size, defined as the number of studies or observations included in the metaanalyses. The collected information is available in Abbasi et al. (2020).

Our purpose in conducting a comparison of existing metaanalyses was to visualize (in)consistencies among metaanalyses and identify variables that have received more (or less) attention. We did not account for overlapping empirical data between meta-analyses and thus do not provide a unified dataset for new analyses. Instead, we present the sample sizes and publication year of each meta-analysis to help interpret the results.

\section{Soil responses to precipitation changes}

\subsection{Responses of soil respiration and belowground biomass}

Meta-analyses on autotrophic $\left(R_{\mathrm{a}}\right)$, heterotrophic $\left(R_{\mathrm{h}}\right)$, and total soil $\left(R_{\mathrm{S}}=R_{\mathrm{a}}+R_{\mathrm{h}}\right)$ respiration provide strong agreement that DP decreases, and IP increases, $R_{\mathrm{S}}, R_{\mathrm{a}}$, and $R_{\mathrm{h}}$ (Fig. 1a). Litter biomass (B) follows the same pattern (Fig. 1b). Although the response of $R_{\mathrm{a}}$ reaches significance in only one of two meta-analyses, the direction of the response is consistent. Responses of soil carbon variables (total carbon, C; soil organic C, SOC; and dissolved organic C, DOC) to precipitation differ among meta-analyses, both in direction and significance (Fig. 1b). Interestingly, root B is strongly suppressed by both DP and IP. In contrast, IP stimulates belowground $\mathrm{B}$ and belowground net primary productivity (NPP), and DP increases root C (Fig. 1b). It is difficult to reconcile that IP suppresses root $\mathrm{B}$ but increases belowground $\mathrm{B}$; the difference between the two measures is that belowground $\mathrm{B}$ includes not just roots but also any other plant or animal-derived materials found in a soil core. We note that these two contrasting results come from different, single meta-analyses with small sample sizes.

To understand the effects of precipitation on $R_{\mathrm{S}}$, we need to understand the responses of roots, microbes, and substrates to DP and IP. When soil moisture is below field capacity and plants are active, $R_{\mathrm{a}}$ and $R_{\mathrm{h}}$ and belowground NPP are typically positively correlated with soil water availability. $R_{\mathrm{a}}$ decreases under limited water supply due to (1) reduced plant growth and nutrient demand, (2) reduced root tissue activity due to limited soil water, and (3) reduced respiratory substrate production from photosynthetic activity (Hasibeder et al., 2015). In contrast, increased water supply increases $R_{\mathrm{a}}$ by enhancing plant growth and photosynthetic rates (HeislerWhite et al., 2008; Maire et al., 2015). In concordance with these plant physiological responses, belowground NPP decreases with DP and increases with IP (Fig. 1; Zhou et al., 
Table 2. List of soil variables and their definitions as analyzed in the meta-analyses. The numbers indicate the meta-analysis number corresponding to Table 1, examining the effects of decreased precipitation (DP) and increased precipitation (IP) on each soil variable.

\begin{tabular}{|c|c|c|c|c|c|c|c|}
\hline Variable & \multicolumn{3}{|c|}{ Definition } & \multicolumn{2}{|l|}{ DP } & \multicolumn{2}{|l|}{ IP } \\
\hline$R_{\mathrm{S}}$ & \multicolumn{3}{|c|}{ Soil respiration } & \multicolumn{2}{|c|}{$\begin{array}{l}3,6,8,9 \\
11,15\end{array}$} & \multicolumn{2}{|c|}{$\begin{array}{l}6,8,9,11 \\
15\end{array}$} \\
\hline$R_{\mathrm{a}}$ & \multicolumn{3}{|c|}{ Autotrophic respiration } & \multicolumn{2}{|c|}{6,15} & \multicolumn{2}{|c|}{6,15} \\
\hline$R_{\mathrm{h}}$ & \multicolumn{3}{|c|}{ Heterotrophic respiration } & \multicolumn{2}{|c|}{$6,8,15$} & \multicolumn{2}{|c|}{$6,8,15$} \\
\hline $\mathrm{CH}_{4}$ & \multicolumn{3}{|c|}{$\mathrm{CH}_{4}$ uptake } & \multicolumn{2}{|c|}{11} & \multicolumn{2}{|c|}{11} \\
\hline Total C & \multicolumn{3}{|c|}{ Total soil C } & \multicolumn{2}{|c|}{$11,12,15$} & \multicolumn{2}{|c|}{$11,12,15$} \\
\hline SOC & \multicolumn{3}{|c|}{ Soil organic C } & \multicolumn{2}{|c|}{8} & \multicolumn{2}{|c|}{8} \\
\hline DOC & \multicolumn{3}{|c|}{ Dissolved organic C } & \multicolumn{2}{|c|}{$3,8,11$} & \multicolumn{2}{|l|}{8,11} \\
\hline Litter B & \multirow{2}{*}{\multicolumn{3}{|c|}{ Litter biomass }} & 11 & & 11 & \\
\hline Root B & Root bion & & & 11 & & 11 & \\
\hline Below B & Belowgro & biomass $^{\mathrm{a}}$ & & Non & & 9 & \\
\hline Below NPP & Belowgro & NPP & & 15 & & 9,15 & \\
\hline Root C & Fine-root & oncentration & & 11 & & 11 & \\
\hline Root N & Fine-root & oncentration & & 11 & & 11 & \\
\hline Root C:N & Fine-root & oncentration: & -root $\mathrm{N}$ concentration & 11 & & 11 & \\
\hline $\mathrm{C}: \mathrm{N}$ & Total soil & & & 11 & & None & \\
\hline $\mathrm{N}_{2} \mathrm{O}$ & $\mathrm{N}_{2} \mathrm{O}$ emi & & & 5,11 & & 11 & \\
\hline Total N & Total soil & & & 11, & 13 & 11,1 & 2,13 \\
\hline Inorganic $\mathrm{N}$ & Inorganic & & & 13 & & 13 & \\
\hline N supply & $\mathrm{N}$ minera & & & 5 & & None & \\
\hline DON & Dissolvec & $\operatorname{anic} \mathrm{N}$ & & 11 & & None & \\
\hline $\mathrm{NH}_{4}^{+}+\mathrm{NO}_{3}^{-}$ & Extractab & $\mathrm{H}_{4}^{+}+\mathrm{NO}_{3}^{-}$ & & 4 & & None & \\
\hline $\mathrm{NH}_{4}^{+}$ & Extractab & & & 5,11 & & 11 & \\
\hline $\mathrm{NO}_{3}^{-}$ & Extractab & & & 5,11 & & 11 & \\
\hline $\mathrm{N}: \mathrm{P}$ & Extractab & & & 4 & & None & \\
\hline Ext $P$ & Extractab & iil P & & 4,1 & & 14 & \\
\hline Total P & Total soil & & & 11, & 14 & 11,1 & 2,14 \\
\hline MB & Microbial & mass & & $\begin{array}{l}3,5 \\
16\end{array}$ & 7, 8, & 1,8, & \\
\hline MBC & Microbial & mass $\mathrm{C}$ & & 11, & & 10,1 &, 15 \\
\hline MBN & Microbial & mass $\mathrm{N}$ & & 11, & & 11,1 & \\
\hline MBC : MBN & Microbial & mass $\mathrm{C}$ : micr & al biomass $\mathrm{N}$ & 11 & & 11 & \\
\hline Bacteria & Abundan & bacteria & & 7,11 & & 1,11 & \\
\hline Fungi & Abundan & fungi & & 7,11 & & 1,11 & \\
\hline Gram+ & Gram pos & bacteria & & 7 & & None & \\
\hline Gram- & Gram neg & e bacteria & & 7 & & None & \\
\hline $\mathrm{F}: \mathrm{B}$ & Fungi : ba & ia ratio & & 3,7 , & & 11 & \\
\hline Hy-enzyme & $\begin{array}{l}\text { C-enzyme } \\
\text { N-enzyme } \\
\text { P-enzyme }\end{array}$ & $\begin{array}{l}\text { Hydrolytic } \\
\text { enzyme } \\
\text { activity }\end{array}$ & $\begin{array}{l}\mathrm{C} \text { acquisition enzymes } \\
\mathrm{N} \text { acquisition enzymes } \\
\mathrm{P} \text { acquisition enzymes }\end{array}$ & 8 & $\begin{array}{l}10 \\
10 \\
10\end{array}$ & 8 & $\begin{array}{l}10 \\
10 \\
10\end{array}$ \\
\hline Ox-enzyme & Oxidase & & & 8,10 & & 8,10 & \\
\hline Pro-enzyme & Potential & eolytic enzym & ctivity & 2 & & 2 & \\
\hline $\begin{array}{l}\text { Soil tempera- } \\
\text { ture }\end{array}$ & Soil temp & & & Non & & 11 & \\
\hline pH & Soil pH & & & 11 & & None & \\
\hline
\end{tabular}

a Belowground biomass was measured by drying soil cores (Wu et al., 2011) and thus includes roots and other plant- and animal-derived materials. Root biomass includes biomass that derives from roots only.

${ }^{\mathrm{b}} \mathrm{C}$ acquisition enzymes are $\beta$-1,4-glucosidase and $\beta$-D-cellobiohydrolase; $\mathrm{N}$ acquisition enzymes are $\beta$-1,4-N-acetyl-glucosaminidase, leucine amino peptidase, and urease; and the $\mathrm{P}$ acquisition enzyme is acid phosphatase (Xiao et al., 2018). 


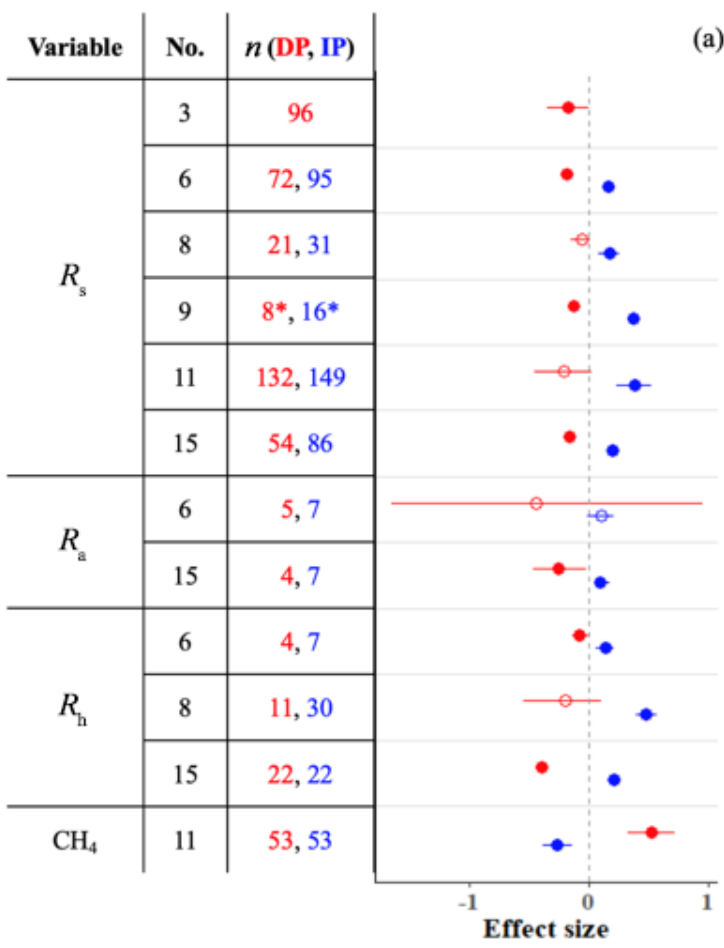

(c) Decreased precipitation

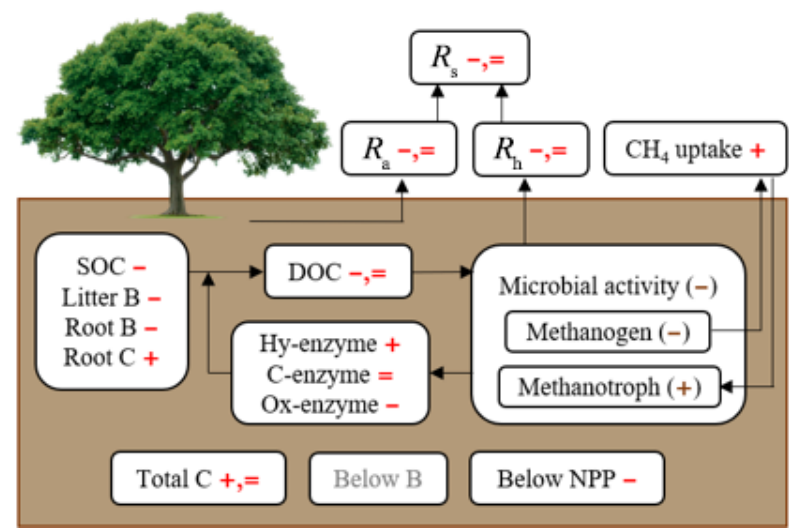

(a)

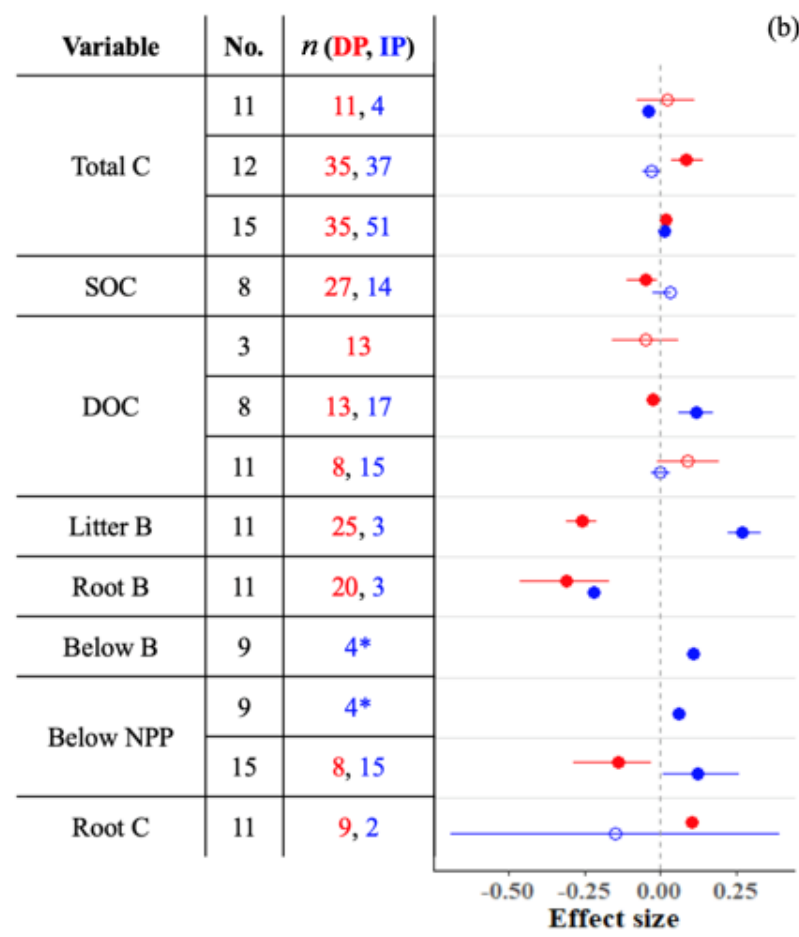

(d) Increased precipitation

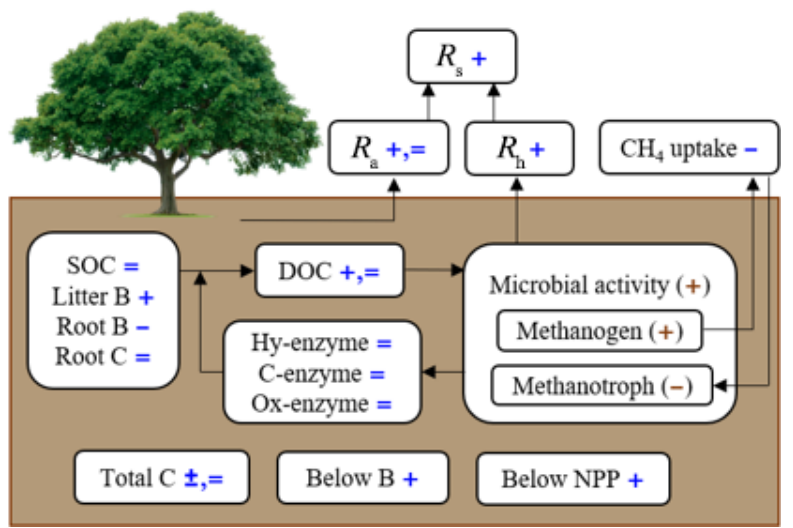

Figure 1. (a,b) Effect sizes for (a) soil respiration and methane uptake and (b) carbon and belowground biomass variables with respect to decreased (red) and increased (blue) precipitation. Filled points represent significant effect sizes (95\% CI not overlapping 0), and open points represent nonsignificant effect sizes. Variable names correspond to Table 2. No. is meta-analysis number as listed in Tables 1 and 2. The sample size is indicated by $n$. Asterisks indicate missing $95 \%$ CIs. (c, d) The effects of (c) decreased precipitation and (d) increased precipitation on the soil carbon cycle. Negative, positive, and nonsignificant effects are represented by,-+ , and $=$, respectively. Red and blue represent variables found in one or more meta-analyses. Brown symbols in parentheses represent the variables that no meta-analyses quantified; in these cases, we estimated the effects based on our review of empirical studies in Sect. 3.1.

2016). Belowground B also increases with IP. However, not all belowground responses follow this pattern; total $\mathrm{C}$ (which is also affected by microbial activity) increases with DP, and root $\mathrm{B}$ - with a very small sample size - decreases with IP (Fig. 1b).

Some responses vary by biome. For example, the effect of $\mathrm{DP}$ on total $\mathrm{C}$ is negative in temperate forests and positive in tropical forests and grassland (Yuan et al., 2017; Zhou et al.,
2016). Total C reflects a balance of plant inputs and microbial outputs, so differences in responses among systems may reflect differences in the strength of PME effects on plants vs. microbes across those systems. Responses of this metric also depend on the size of the initial pool relative to fluxes and so may be differentially dampened across systems.

Responses of $R_{\mathrm{a}}$ to DP and IP were either significant (Zhou et al., 2016) or nonsignificant (Liu et al., 2016), de- 
pending on the study (although the mean responses were consistent in direction across studies). The difference in significance could be attributed to small samples sizes and high variability in the case of DP. The samples sizes are somewhat larger for IP effects on $R_{\mathrm{a}}$, and these responses depend on biome and $R_{\mathrm{a}}$ separation method. For instance, significant IP effects were found in temperate forest and grassland but not in boreal forest (Zhou et al., 2016), and $R_{\mathrm{a}}$ separated from $R_{\mathrm{h}}$ by clipping methods responded more positively than when trenching methods were used (Liu et al., 2016). Nonetheless, sample sizes remain relatively small, suggesting that additional research could help to identify how this process response varies with biomes and methods.

$R_{\mathrm{h}}$ is the consequence of soil microbial activity decomposing soil organic matter (SOM) under aerobic conditions. SOM is frequently estimated by measuring its carbon component, SOC. $R_{\mathrm{h}}$ is mainly regulated by microbial access to substrate and the physiological condition of microbes (Schimel, 2018). In dry soil, substrate tends to be isolated from microbes as solute mobility is low (Manzoni et al., 2012; Schimel, 2018). Furthermore, a great number of empirical observations and synthetic studies have shown that microbial activity is lower during droughts (Hueso et al., 2012; Jensen et al., 2003; Manzoni et al., 2012). This is because dry conditions force microbes into dormancy or shift their efforts from growth to survival (Salazar et al., 2018; Schimel et al., 2007). Wetting of dry soil, on the other hand, increases substrate availability to microbes (Skopp et al., 1990), makes microbes dispose of osmolytes from their body cells to regulate osmotic pressure (Schimel et al., 2007), and can activate dormant microbes (Salazar et al., 2018). These responses can be particularly rapid and strong, yielding pulses of respiration that are large enough to affect the net carbon exchanges in terrestrial ecosystems (Placella et al., 2012).

As with $R_{\mathrm{a}}, R_{\mathrm{h}}$ typically decreases under DP and increases under IP, with variations among biomes and $R_{\mathrm{h}}$ separation methods. DP effects on $R_{\mathrm{h}}$ are significant in boreal forest and wetland but not in tropical and temperate forests (Zhou et al., 2016). Likewise, IP effects on $R_{\mathrm{h}}$ are significant in forest and grassland but not in wetland (Liu et al., 2016; Zhou et al., 2016). We hesitate to draw strong conclusions from these differences because of the relatively small sample sizes. Zhou et al. (2016), for example, have a sample size of four and five for the tropical and temperate forests, respectively, for DP, and the effects are highly uncertain. The biomes with significant effects - wetlands under DP and grasslands under IP - have higher sample sizes, of 10 and 15, respectively. Biological mechanisms behind these differences can also be hypothesized, such as differences in microbial sensitivity to moisture across systems. Furthermore, the effects of DP and IP on soil respiration can depend on methodological factors of the field experiments not explicitly considered in all metaanalyses. For example, the effects of IP on $R_{\mathrm{a}}$ can be significant when fieldwork included clipping but not when it included trenching (Liu et al., 2016).

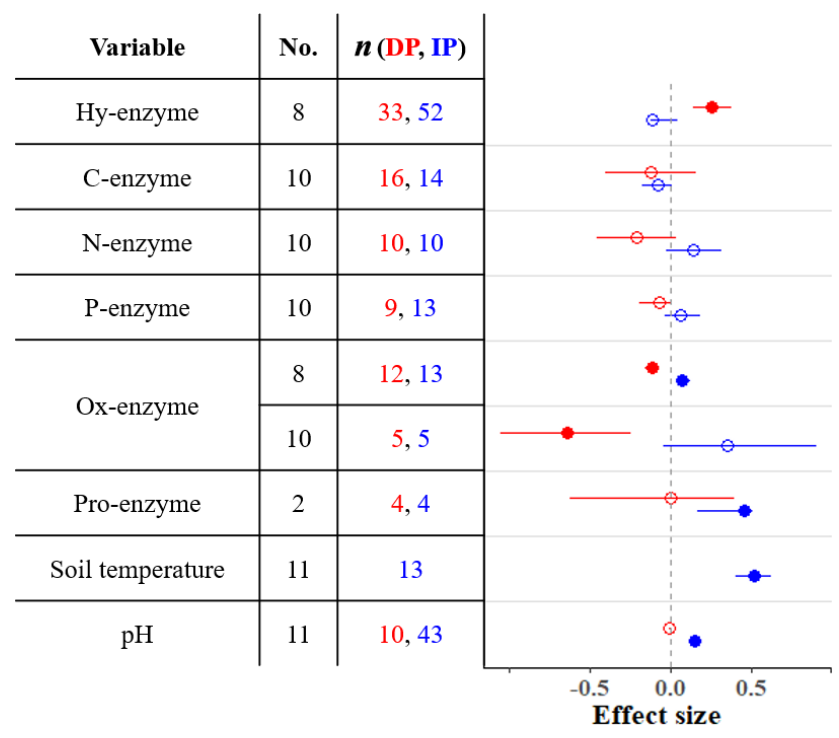

Figure 2. Effect sizes for soil enzyme and physical variables with respect to decreased (red) and increased (blue) precipitation. Filled points represent a significant effect size (95\% CI not overlapping 0 ), and open points represent a nonsignificant effect size. Variable names correspond to Table 2. No. is meta-analysis number as listed in Tables 1 and 2. The sample size is indicated by $n$.

Overall, responses of $R_{\mathrm{S}}, R_{\mathrm{a}}$, and $R_{\mathrm{h}}$ are positively correlated with precipitation changes and soil moisture (Liu et al., 2016; Ren et al., 2017; Zhou et al., 2016). Responses of SOC, DOC, and belowground NPP also tend to be positively correlated with precipitation changes (Ren et al., 2017; Zhou et al., 2016). Despite the broad agreement among meta-analyses, the responses of respiration and soil carbon vary across studies and can depend on biome, measurement method, treatment intensity, and other factors.

Microbial activity in soils is strongly controlled by the actions of enzymes (Ren et al., 2017). Many of these enzymes, which are produced and released by microbes, depolymerize complex carbon compounds (Ren et al., 2017). While enzyme activity is relatively unresponsive to IP (Fig. 2), DP increases hydrolytic enzyme activity (breakdown of labile carbon) and inhibits oxidative activity (depolymerization of recalcitrant carbon; Fig. 2). This indicates that under dry conditions, the relative contributions of substrates from labile carbon sources increase, while the respective relative contributions from recalcitrant sources decrease.

The summary diagrams (Fig. 1c and d) illustrate how DP generally slows the belowground carbon cycle, while IP promotes it. Nearly all steps of the carbon cycle - carbon stock, substrates, microbial activity, and respiration - are altered by both types of precipitation changes. However, enzyme activity tends to be relatively unresponsive, particularly to IP, and the observations of biomass and carbon variables vary both in direction and significance among meta-analyses. These vari- 
ables also tend to vary across biomes, ecosystems, and soil types.

\subsection{Responses of methane uptake}

We found only one meta-analysis that addressed the effects of precipitation on soil $\mathrm{CH}_{4}$ (Yan et al., 2018). The results show a significant increase and decrease in soil $\mathrm{CH}_{4}$ uptake in response to DP and IP, respectively (Fig. 1a). Soil $\mathrm{CH}_{4}$ fluxes involve two groups of microbes: methanogens and methanotrophs. Methanogens produce $\mathrm{CH}_{4}$ and are predominantly active in anaerobic conditions, while methanotrophs oxidize $\mathrm{CH}_{4}$ and are active in aerobic environments (Conrad, 2007). $\mathrm{CH}_{4}$ oxidation seems to peak at $10 \%-15 \%$ volumetric water content because these conditions favor methanotroph activity as well as $\mathrm{CH}_{4}$ and $\mathrm{O}_{2}$ diffusion (Adamsen and King, 1993; Del Grosso et al., 2000).

The results of Yan et al. (2018) were significant across a wide range of ecosystem types, treatment durations, and magnitudes of precipitation manipulation. The effects of DP were greater in farmlands than in other land types, in shorterterm $(<1$ year) experiments than in longer-term ones, and in more extreme experiments ( $>50 \%$ rain reduction). The effects of IP were greatest in boreal forest and in longer-term experiments ( $1-5$ years) with greater rain addition $(>50 \%)$. However, a few empirical studies have shown opposite responses to this meta-analysis (Billings et al., 2000; Christiansen et al., 2015); for instance, a precipitation removal experiment in a floodplain decreased $\mathrm{CH}_{4}$ uptake, possibly due to the acclimation of methanotrophs to high-soil-moisture conditions (Billings et al., 2000) or due to differences in the types of methanotrophs in floodplain (low-affinity methanotrophs) vs. upland soil, where most $\mathrm{CH}_{4}$ uptake occurs (Christiansen et al., 2015).

\subsection{Responses of soil nitrogen dynamics}

Several soil nitrogen variables, including root nitrogen $(\mathrm{N})$, $\mathrm{N}_{2} \mathrm{O}$ emissions, total $\mathrm{N}$, dissolved organic nitrogen (DON), and extractable $\mathrm{NH}_{4}^{+}+\mathrm{NO}_{3}^{-}$, are significantly affected by precipitation changes (Fig. 3a). Specifically, DP decreases root $\mathrm{N}$ and $\mathrm{N}_{2} \mathrm{O}$ emissions and increases total $\mathrm{N}$, DON, and extractable $\mathrm{NH}_{4}^{+}+\mathrm{NO}_{3}^{-}$. We also found that two metaanalyses (sample sizes $<20$ ) suggest no change in total $\mathrm{N}$, while one (sample size $=156$ ) suggests an increase with DP. Similarly, one meta-analysis suggests an increase in extractable $\mathrm{NH}_{4}^{+}$with DP, while two other meta-analyses suggest no effects. In contrast, IP increases root $\mathrm{N}, \mathrm{N}_{2} \mathrm{O}$ emissions, and extractable $\mathrm{NH}_{4}^{+}$(Fig. 3a). Two meta-analyses suggest that total $\mathrm{N}$ decreases with IP, while one metaanalysis suggests no effects.

Mineralization rate, defined as $\mathrm{N}$ supply by Homyak et al. (2017), does not change under DP despite the increase in substrate (i.e., DON; Fig. 3). However, the product of mineralization and $\mathrm{N}_{2}$ fixation is $\mathrm{NH}_{4}^{+}$, which increases under
DP according to one of three meta-analyses (Homyak et al., 2017) even though fixation could be suppressed (Hume et al., 1976; Streeter, 2003). This is reasonable considering that the consumption of $\mathrm{NH}_{4}^{+}$is likely to decrease with DP, mainly because of reduced plant nitrogen uptake (He and Dijkstra, 2014; Matías et al., 2011; Yuan et al., 2017) and microbial nitrogen assimilation (Homyak et al., 2017; Månsson et al., 2014). Homyak et al. (2017) found the increase in extractable $\mathrm{NH}_{4}^{+}$is greater under more intense DP. Nitrification and denitrification are expected to slow down with DP (Bouwman, 1998; Lennon et al., 2012; Stark and Firestone, 1995), also reducing $\mathrm{N}_{2} \mathrm{O}$ emission (Fig. 3b). This suggests that soil moisture could be a stronger regulator of nitrification and denitrification processes than the availability of $\mathrm{NH}_{4}^{+}$ and $\mathrm{NO}_{3}^{-}$(Weier et al., 1993). The input (nitrification) and outputs (denitrification, plant uptake, and microbial assimilation) of $\mathrm{NO}_{3}^{-}$both decline under $\mathrm{DP}$, leaving extractable $\mathrm{NO}_{3}^{-}$unchanged (Fig. 3b).

Extracellular enzyme activity, here shown as both total proteolytic activity (pro-enzyme) and three particular $\mathrm{N}$ acquisition enzyme activities $(\beta-1,4-\mathrm{N}$-acetylglucosaminidase, leucine amino peptidase, and urease), does not change with DP or IP (Fig. 2). This indicates that the production of N-enzymes is not sensitive to water stress. Important outputs of the soil nitrogen cycle (denitrification and plant uptake) decrease while inputs remain constant or decline (Fig. 3b). As a result, total soil $\mathrm{N}$ increases or remains unchanged.

In contrast to DP, soil nitrogen cycling is accelerated by IP (Fig. 3c). Although no mineralization indicator was included in the meta-analyses, ample evidence shows that nitrogen mineralization is likely to increase with IP (Hu et al., 2014; Sierra, 1997; Pilbeam et al., 1993; Mazzarino et al., 1998). Along with greater $\mathrm{N}_{2}$ fixation (Hume et al., 1976), which contributes to increasing $\mathrm{NH}_{4}^{+}$(Fig. 3c), positive responses are also expected in nitrification and denitrification rates (Bouwman, 1998; Niboyet et al., 2011; Stark and Firestone, 1995), plant nitrogen uptake (Schaeffer et al., 2013; Liu et al., 2016; Ma et al., 2013), and microbial nitrogen assimilation (Månsson et al., 2014), which result in increased $\mathrm{N}_{2} \mathrm{O}$ emissions and lead to unchanged $\mathrm{NO}_{3}^{-}$as well as total N.

Soil nitrogen undergoes a wide range of chemical and biological transformations, some of which are difficult to quantify. Despite the large number of empirical studies included in meta-analyses, some nitrogen variables, such as rates of mineralization (for IP), nitrification, denitrification, and $\mathrm{N}_{2}$ fixation, have not yet been examined in meta-analyses focused on PMEs.

\subsection{Responses of soil phosphorus}

We found four meta-analyses that examined how precipitation changes affect the soil phosphorus $(\mathrm{P})$ cycle $(\mathrm{He}$ and $\mathrm{Di}$ jkstra, 2014; Yan et al., 2018; Yuan et al., 2017; Yue et al., 
(a)

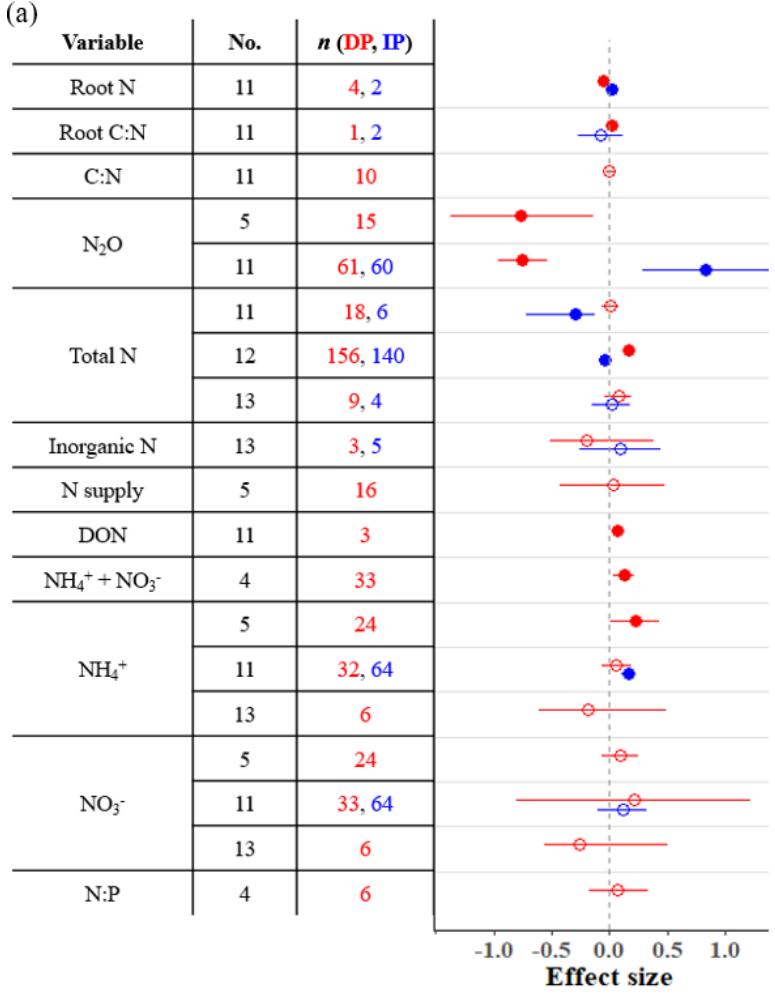

(b) Decreased precipitation

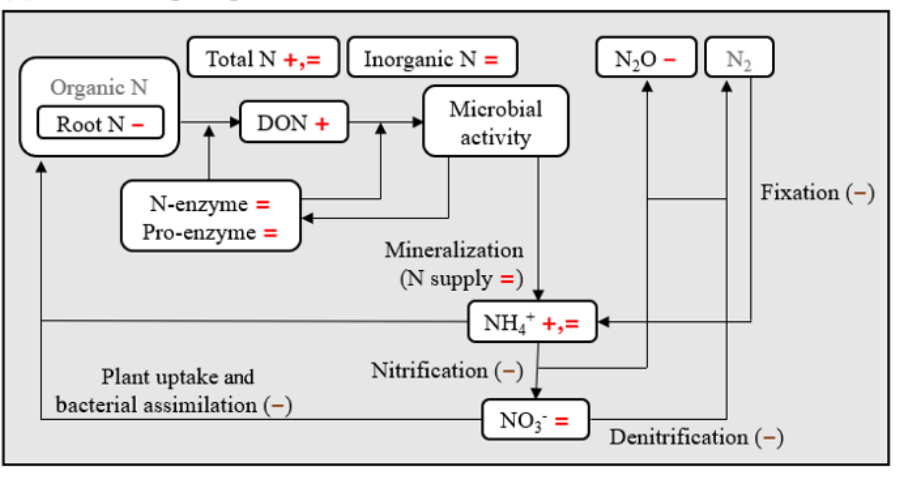

(c) Increased precipitation

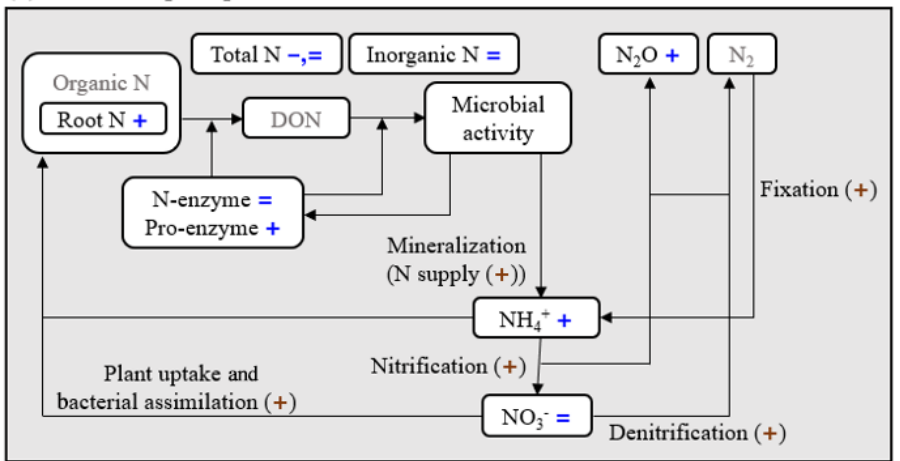

Figure 3. (a) Effect sizes for soil nitrogen variables responding to decreased (red) and increased (blue) precipitation. Filled points represent a significant effect size (95\% CI not overlapping 0), and open points represent a nonsignificant effect size. Variable names correspond to Table 2. No. is meta-analysis number as listed in Tables 1 and 2 . The sample size is indicated by $n$. (b, c) The effects of (b) decreased precipitation and (c) increased precipitation on a simplified schematic of the soil nitrogen cycle. Negative, positive, and nonsignificant effects are represented by,-+ , and $=$, respectively. These symbols are colored in red and blue if variables are found in one or more meta-analyses. Brown symbols in parentheses represent variables that no meta-analyses have quantified; in these cases, we estimated the effects based on our review of empirical studies in Sect. 3.3.

2018). The results differ among meta-analyses; for instance, according to these meta-analyses, IP can have a negative, positive, or nonsignificant effect on total $\mathrm{P}$ (Fig. 4). Yuan et al. (2017) assembled the largest dataset and found that IP decreases total P, while DP increases total P. As phosphorus is commonly a limiting nutrient for vegetation, plant $\mathrm{P}$ uptake and concentration are frequently studied, but studies of soil phosphorus stocks are rarer (He and Dijkstra, 2014; Yue et al., 2018). The timescale of precipitation experiments can be as short as one growing season (or less), and the effect of such short-term precipitation manipulations on slow processes such as chemical weathering is negligible. However, phosphorus cycling through faster processes such as decomposition of organic matter, plant uptake, and consumption by microbes can respond (Van Meeteren et al., 2007). Plant P uptake tracks in the same direction as changes in precipitation (He and Dijkstra, 2014). The effects on total P are strongly linked to soil type (Yuan et al., 2017). Although Yuan et al. (2017) found significant effects of DP and IP on total $P$, the effects were small $(-0.1<$ effect sizes $<0.1)$, and other meta-analyses show that soil $\mathrm{P}$, as well as $\mathrm{P}$ acquisi- tion enzyme activity, is relatively unresponsive to precipitation changes (Figs. 2 and 4). Other global changes such as warming, elevated $\mathrm{CO}_{2}$, and anthropogenic $\mathrm{P}$ and $\mathrm{N}$ deposition tend to have stronger impacts on the terrestrial $\mathrm{P}$ cycle than precipitation changes (Yue et al., 2018).

\subsection{Responses of microbial biomass and community structure}

Microbial biomass (MB) in soil either decreases or does not respond to DP (Fig. 5a), and these responses depend on the amount of precipitation removed (Zhou et al., 2016; Ren et al., 2017, 2018), the length of droughts (Ren et al., 2018), vegetation type (Zhou et al., 2016; Ren et al., 2017, 2018), and mean annual precipitation (MAP; Ren et al., 2017). MB is affected by DP only when precipitation is reduced by more than $\sim 33 \%$ (Ren et al., 2017, 2018), the drought period is $\leq 2$ years (Ren et al., 2018), and the region is wet (MAP > $600 \mathrm{~mm}$; Ren et al., 2017). Additionally, vegetation type affects MB responses to DP; DP consistently decreases $\mathrm{MB}$ in forests (tropical and temperate but not in boreal; Zhou 


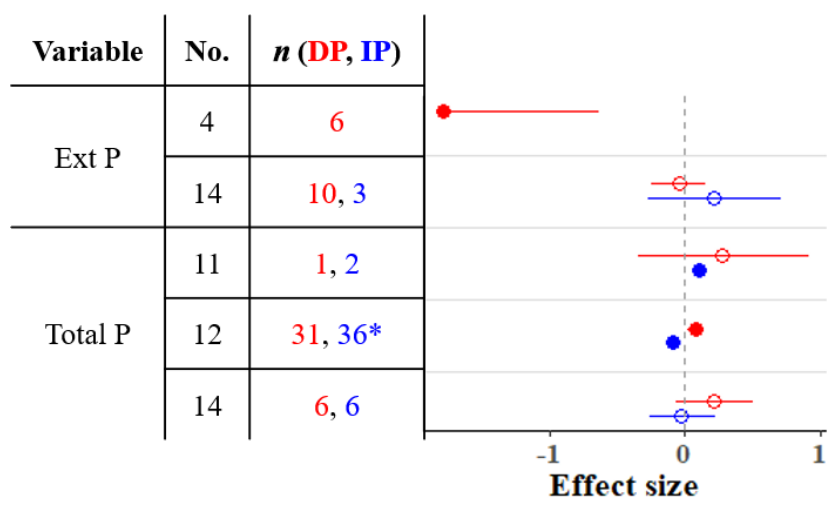

Figure 4. Effect sizes for soil phosphorus variables responding to decreased (red) and increased (blue) precipitation. Filled points represent a significant effect size (95\% CI not overlapping 0), and open points represent a nonsignificant effect size. Variable names correspond to Table 2. No. is meta-analysis number as listed in Tables 1 and 2 . The sample size is indicated by $n$. Asterisks indicate missing $95 \%$ CIs.

et al., 2016; Ren et al., 2017, 2018) and heathlands (Blankinship et al., 2011) but not in shrublands (Ren et al., 2017, 2018). A meta-analysis conducted by Zhou et al. (2016) found that DP decreases MB in grassland soils. However, more recent meta-analyses that included more studies (Ren et al., 2017, 2018) suggest that MB in grasslands does not respond to DP.

In contrast, IP stimulates microbial growth and thus increases $\mathrm{MB}$ unless the proportion added is very high ( $>+70 \%$; Ren et al., 2017). Unlike DP, IP affects MB in dry (MAP $>600 \mathrm{~mm}$ ) but not in wet (MAP $>600 \mathrm{~mm}$ ) sites (Ren et al., 2017). This is consistent with IP increasing MB in soils from ecosystems that are generally water-stressed, such as deserts, shrublands, and grasslands (Zhou et al., 2016; Ren et al., 2017). Zhou et al. (2016) found that IP increases MB in soils in temperate forests. Other meta-analyses that included more studies (also including tropical forests) suggest that MB in forest soils is generally not affected by IP (Blankinship et al., 2011; Canarini et al., 2017; Ren et al., 2017). Overall, increased precipitation in water-limited systems increases water availability in soil and typically increases MB.

In contrast to the responsiveness of MB to altered precipitation, the composition of bacterial and fungal communities is rather unresponsive (Fig. 5b). Although Blankinship et al. (2011) and Yan et al. (2018) estimated significant effects on the abundance of fungi (both positive and negative effects of IP) and $\mathrm{F}: \mathrm{B}$ ratio (negative effect of DP; $n=4$ ), other studies with sample sizes an order of magnitude larger (e.g., Ren et al., 2018) estimated nonsignificant effects. The high resistance of bacteria and fungi to soil moisture changes has been frequently highlighted (Evans and Wallenstein, 2012; Schimel et al., 2007; Yuste et al., 2011). Fungi in particular, due to their filamentous structure, are capable of accessing substrates even in very dry soils (Manzoni et al., 2012). Bacteria and fungi also have a wide breadth of soil moisture niches; diverse types of bacteria and fungi tolerate water stress (Lennon et al., 2012). Differences in resistance between bacteria, fungi, and other functional types can alter microbial structure under precipitation changes; DP could promote a more fungi-dominated community (Yuste et al., 2011). Although gram-positive bacteria are more resistant to soil moisture changes than gram-negative bacteria due to their thicker and stronger cell walls (Schimel et al., 2007; Salazar et al., 2019), both gram-positive and gramnegative bacteria have been unresponsive to DP (Fig. 5b). The sample sizes for bacteria and fungi in meta-analyses are small compared to MB meta-analyses (Fig. 5). Although the currently available data cover a substantial range of locations and conditions, microbial responses within each site are likely to vary by treatment timing, intensity, frequency, and other environmental and climatic factors (Bell et al., 2014; Zhao et al., 2016). Future studies of bacterial and fungal community responses can improve our understanding of the microbial responses to precipitation in terms of the composition and structure of the microbial community by more comprehensively exploring these factors.

\subsection{Responses of belowground $\mathrm{C}: \mathrm{N}: \mathrm{P}$ stoichiometry}

Belowground stoichiometric relationships of carbon, nitrogen, and phosphorus can help researchers interpret and infer nutrient movements in soil organisms and their environments. Yet, few meta-analyses have synthesized belowground stoichiometric responses to precipitation treatments; greater attention has been paid to stoichiometry of aquatic systems and plants (Cleveland and Liptzin, 2007; Redfield, 1958; Yuan and Chen, 2015). He and Dijkstra (2014) and Yan et al. (2018) found no changes in soil $\mathrm{C}: \mathrm{N}$ and $\mathrm{N}: \mathrm{P}$ with DP (Fig. 3), but MBC : MBN responded to both precipitation changes (Fig. 5). Increased MBC: MBN with IP indicates that wetter conditions stimulated greater metabolic activity of microbes, which accumulated more carbon in their bodies. This suggests that the soil microbial biomass $\mathrm{C}: \mathrm{N}: \mathrm{P}$ ratio, which is well-constrained globally $(60: 7: 1$; Cleveland and Liptzin, 2007), could be altered by IP to have more weight on carbon. Soil N : P ratios can be heavily dependent on plant nutrient uptake; as discussed in Sect. 3.3, DP reduces plant nitrogen uptake, which could increase soil N:P. However, this effect depends on site aridity (Sardans et al., 2012) and could be mitigated by robust mycorrhizal symbioses (Mariotte et al., 2017), which could help maintain soil N : P ratios by sustaining plant nutrient uptake under DP.

\section{Implications for future research}

\subsection{Knowledge gaps}

Meta-analyses have substantially advanced our understanding of the impacts of precipitation changes on soil processes 

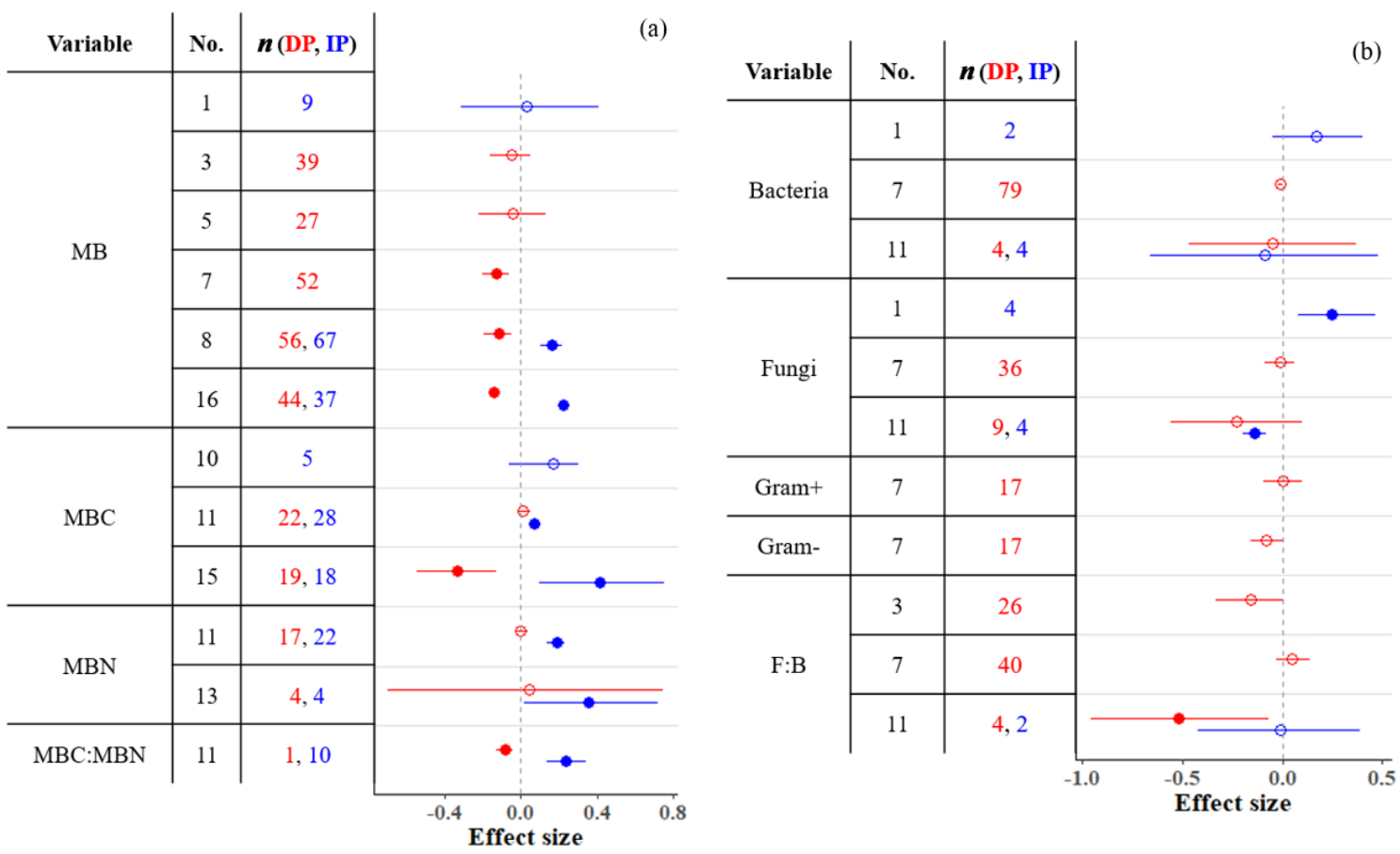

Figure 5. Effect sizes for (a) microbial biomass, carbon, and nitrogen and (b) bacterial and fungal variables responding to decreased (red) and increased (blue) precipitation. Filled points represent significant effect sizes (95\% CI not overlapping 0), and open points represent nonsignificant effect sizes. Variable names correspond to Table 2. No. is meta-analysis number as listed in Tables 1 and 2 . The sample size is indicated by $n$.

and properties. Responses of several variables have been investigated by three or more meta-analyses and with robust datasets; these include soil respiration, nitrogen stocks, total phosphorus, and microbial biomass. However, many other variables have received less attention. For example, sample sizes for analyses of autotrophic respiration are smaller than for those of heterotrophic respiration; substrate availability has not been analyzed while soil $\mathrm{C}, \mathrm{N}$, and $\mathrm{P}$ content have; and analyses of bacterial and fungal responses to IP are sparser than those of responses to DP. $\mathrm{CH}_{4}$ fluxes have received less attention than $\mathrm{CO}_{2}$ and $\mathrm{N}_{2} \mathrm{O}$, and no metaanalyses have examined the processes of nitrification, denitrification, and nitrogen fixation.

Filling these knowledge gaps could help to reveal the mechanisms underlying soil responses to precipitation changes. For example, there is robust agreement across studies that soil and heterotrophic respiration slow under DP and accelerate under IP. However, the relative importance of different mechanisms in the response of heterotrophic respiration is still unknown - in other words, how much of this response comes from changes in the level of microbial activity (e.g., entering and exiting dormancy) vs. substrate availability? Similarly, what are the most important mechanisms behind changes in $\mathrm{N}_{2} \mathrm{O}$ emissions, and how quickly will total soil nitrogen respond? Interestingly, the variables receiving the greatest attention are largely the easier-to-measure "fluxes" (i.e., greenhouse gas emissions) and "pools" (i.e., soil carbon, biomass, and bacterial abundance).

Studies of processes that have received less attention (e.g., microbial metabolic state, nitrification, denitrification, and $\mathrm{N}$ fixation) have the potential to inform models and improve predictions of the effects of precipitation changes on important fluxes and pools. This benefit can be seen in ecosystem models that explicitly represent active and dormant microbial biomass, which can outperform those representing microbial biomass as a single pool (He et al., 2015; Salazar et al., 2019; Wang et al., 2015). A more synthetic understanding of nitrification and denitrification responses across ecosystems could improve projections of societally relevant nitrate leaching and soil emissions of $\mathrm{N}_{2} \mathrm{O}$ and $\mathrm{NO}_{x}$ and inform carbonassociated modeling, as the availability of $\mathrm{N}$ in ecosystems has a close connection with $\mathrm{C}$ sequestration (Barnard et al., 2005).

The meta-analyses we examined had strong geographical imbalances, as has been identified elsewhere. While all but one meta-analyses collected global empirical data, the data are concentrated in the US, Europe, and China. Almost $90 \%$ of the existing PMEs are located at midlatitudes $\left(30-60^{\circ}\right)$, and there is an obvious sparsity at lower and higher latitudes (Beier et al., 2012). As a result, sample sizes for tropical and boreal ecosystems are substantially smaller than for temperate ecosystems in many of the meta-analyses. Studies of the effect of IP on $R_{\mathrm{S}}$ provide good examples: Zhou et al. (2016) 
has a sample size of 13 for temperate forest but a sample size of only two for tropical forest and zero for boreal forest. Yan et al. (2018) feature a larger sample size of 66 for temperate forest but still have only four subtropical forest samples and two in boreal forest. The comprehensive meta-analysis recently conducted by Song et al. (2019) has similar geographical gaps. Expanding PMEs to the underrepresented regions is critical in order to obtain a truly planetary synthesis.

\subsection{Challenges in meta-analyses and synthetic studies}

PMEs are quite diverse, adopting a variety of approaches, treatment levels, and treatment types (Beier et al., 2012; Kreyling and Beier, 2013), and so are the data derived from them. Many PMEs use long-term rainout shelters, which unavoidably modify the ambient environment in other ways (Kreyling et al., 2017). While synthesizing the results of PMEs around the globe in the context of these experimental issues could be challenging, meta-analyses provide one somewhat simplistic approach, through an exhaustive statistical summary of empirical studies (Hedges et al., 1999). Meta-analysis can obscure the substantial influence of environmental characteristics and methodological differences on effect sizes. Categorization by environmental characteristics, such as climate, geography, ecosystem, soil, and soil biota, can provide a local to regional view of soil responses that is specific to the given environmental characteristic. Categorization by methodology, such as experimental duration, intensity of treatment, measurement method, and fertilizer use, can clarify the human-derived impacts on effect sizes. These categorization efforts help to identify when and how soil responses depend on their environmental context. While an exhaustive analysis of these categories is beyond the scope of this paper, we have highlighted the cases in which these factors affected each meta-analysis result in the text above. A further breakdown of these categories by environmental characteristics and methodology can be found in the Supplement (S1). As more and more PMEs are implemented, sample sizes available for meta-analysis are increasing (Song et al., 2019). In this regard, the recent deployment of broad networks of PMEs with standardized methodology and sampling procedures (Fraser et al., 2013; Halbritter et al., 2020) could ultimately contribute to more powerful meta-analyses with more easily interpreted outcomes (Hilton et al., 2019; Knapp et al., 2012, 2017).

We identified some technical challenges during this comparative study, including data collection and the definition of samples. Data collection is perhaps the most time-consuming process of searching literature and contacting researchers. Most meta-analyses extract effect size, SD, and sample size from publication when possible, commonly with the use of digitizing software (Canarini et al., 2017; Liu et al., 2016; Ren et al., 2017; Xiao et al., 2018; Yan et al., 2018; and others). While digitizing software is helpful, the accuracy of the digitized values depends on the resolution of the figures.
In some cases, digitizing is not feasible when points are too large or error bars are too close to the points. Thus, we emphasize the importance of comprehensively presenting and publishing data, both in original studies and meta-analyses, to minimize errors associated with digitizing. Secondly, we found that the definition of a sample used in meta-analyses differs by studies. Specifically, some meta-analyses treat observations over multiple years from the same experiment as distinct individual samples, which could potentially violate the assumption of sample independence. We recommend, therefore, that a meta-analysis accounts for within-study dependency (Canarini et al., 2017) or selects a single year or season to include in the analysis.

\section{Conclusions}

This assessment of meta-analyses provides a broad perspective on how precipitation changes affect soils and belowground processes. Belowground carbon and nitrogen cycles speed up with increased precipitation and slow down with decreased precipitation, while bacterial and fungal communities are relatively insensitive to decreased precipitation. While the responses of the fluxes and pools of each cycle gas emissions, soil carbon, nitrogen ions, and biomass - have been studied extensively, responses of the associated process rates remain less studied or unexamined by meta-analyses. There are also gaps in the study of soil elements such as phosphorus and nitrogen ions, as well as of stoichiometric relationships and bacterial and fungal biomass under increased precipitation. We suggest that additional scientific attention to these gaps is warranted and would help to deepen and consolidate current knowledge of soil responses to precipitation changes.

Data availability. The data collected from meta-analyses and used in this paper are available through the Purdue University Research Repository (https://doi.org/10.4231/16NT-CW47).

Supplement. The supplement related to this article is available online at: https://doi.org/10.5194/bg-17-3859-2020-supplement.

Author contributions. AOA, AS, YO, MRU, IR, and JSD designed the research. AOA, AS, YO, SR, MRU, JL, and IR conducted the comparative analysis and contributed to writing the original draft. AOA prepared the manuscript with contributions from all coauthors.

Competing interests. The authors declare that they have no conflict of interest. 
Acknowledgements. Ideas for this paper were developed during a distributed graduate seminar organized by the Drought-Net Research Coordination Network (RCN) in spring 2017. Drought-Net was supported by the NSF (DEB-1354732; PIs (principal investigators) Melinda Smith, Osvaldo Sala, and Richard Phillips). We thank Melinda Smith, Osvaldo Sala, and Alan Knapp for valuable feedback to this research. This is publication 2002 of the Purdue Climate Change Research Center.

Financial support. This research has been supported by the Department of Forestry and Natural Resources at Purdue University and Takenaka Scholarship Foundation in Tokyo, Japan (AOA); the 529 Colciencias-Fulbright grant; the Icelandic Research Fund 2016 (grant no. 163336-052); the POA funds from the Instituto de Investigación de Recursos Biológicos Alexander von Humboldt, Bogotá, Colombia (AS); the Natural Environment Research Council award number NE/R016429/1 as part of the UK-SCAPE program delivering National Capability (SR); and the University Grants Commission, India, under Raman Fellowship Program (IR).

Review statement. This paper was edited by Kees Jan van Groenigen and reviewed by Feike Dijkstra and Nameer Baker.

\section{References}

Abbasi, A. O., Salazar, A., Oh, Y., Reinsch, S., Uribe, M. R., Li, J., Rashid, I., and Dukes, J. S.: Soil responses to manipulated precipitation changes: A synthesis of meta-analysis, Purdue University Research Repository, https://doi.org/10.4231/16NT-CW47, 2020.

Adamsen, A. P. S. and King, G. M.: Methane consumption in temperate and subarctic forest soils: rates, vertical zonation, and responses to water and nitrogen, Appl. Environ. Microb., 59, 485490, 1993.

Bao, J., Sherwood, S. C., Alexander, L. V., and Evans, J. P.: Future increases in extreme precipitation exceed observed scaling rates, Nat. Clim. Change, 7, 128-132, https://doi.org/10.1038/nclimate3201, 2017.

Bardgett, R. D., Freeman, C., and Ostle, N. J.: Microbial contributions to climate change through carbon cycle feedbacks, ISME J., 2, 805-814, https://doi.org/10.1038/ismej.2008.58, 2008.

Barnard, R., Leadley, P. W., and Hungate, B. A.: Global change, nitrification, and denitrification: A review, Global Biogechem. Cy., 19, GB1007, https://doi.org/10.1029/2004GB002282, 2005.

Beier, C., Beierkuhnlein, C., Wohlgemuth, T., Penuelas, J., Emmett, B., Körner, C., de Boeck, H., Christensen, J. H., Leuzinger, S., Janssens, I. A., and Hansen, K.: Precipitation manipulation experiments - challenges and recommendations for the future, Ecol. Lett., 15, 899-911, https://doi.org/10.1111/j.14610248.2012.01793.x, 2012.

Bell, C. W., Tissue, D. T., Loik, M. E., Wallenstein, M. D., AcostaMartinez, V., Erickson, R. A., and Zak, J. C.: Soil microbial and nutrient responses to 7 years of seasonally altered precipitation in a Chihuahuan Desert grassland, Glob. Change Biol., 20, 16571673, https://doi.org/10.1111/gcb.12418, 2014.
Billings, S. A., Richter, D. D., and Yarie, J.: Sensitivity of soil methane fluxes to reduced precipitation in boreal forest soils, Soil Biol. Biochem., 32, 1431-1441, https://doi.org/10.1016/S00380717(00)00061-4, 2000.

Blankinship, J., Niklaus, P. A., and Hungate, B. A.: A meta-analysis of responses of soil biota to global change, Oecologia, 165, 553565, https://doi.org/10.1007/s00442-011-1909-0, 2011.

Borken, W., Savage, K., Davidson, E. A., and Trumbore, S. E.: Effects of experimental drought on soil respiration and radiocarbon efflux from a temperate forest soil, Glob. Change Biol., 12, 177193, https://doi.org/10.1111/j.1365-2486.2005.001058.x, 2006.

Bouwman, A. F.: Nitrogen oxides and tropical agriculture, Nature, 392, 866-867, https://doi.org/10.1038/31809, 1998.

Brockett, B. F. T., Prescott, C. E., and Grayston, S. J.: Soil moisture is the major factor influencing microbial community structure and enzyme activities across seven biogeoclimatic zones in western Canada, Soil Biol. Biochem., 44, 9-20, https://doi.org/10.1016/j.soilbio.2011.09.003, 2012.

Brzostek, E. R., Blair, J. M., Dukes, J. S., Frey, S. D., Hobbie, S. E., Melillo, J. M., Mitchell, R. J., Pendall, E., Reich, P. B., Shaver, G. R., Stefanski, A., Tjoelker, M. G., and Finzi, A. C.: The effect of experimental warming and precipitation change on proteolytic enzyme activity: positive feedbacks to nitrogen availability are not universal, Glob. Change Biol., 18, 2617-2625, https://doi.org/10.1111/j.1365-2486.2012.02685.x, 2012.

Canarini, A., Kiær, L. P., and Dijkstra, F.: Soil carbon loss regulated by drought intensity and available substrate: A meta-analysis, Soil Biol. Biochem., 112, 90-99, https://doi.org/10.1016/j.soilbio.2017.04.020, 2017.

Christiansen, J. R., Romero, A. J. B., Jørgensen, N. O. G., Glaring, M. A., Jørgensen, C. J., Berg, L. K., and Elberling, B.: Methane fluxes and the functional groups of methanotrophs and methanogens in a young Arctic landscape on Disko Island, West Greenland, Biogeochemistry, 122, 15-33, https://doi.org/10.1007/s10533-014-0026-7, 2015.

Cleveland, C. C. and Liptzin, D.: C:N : P stoichiometry in soil: is there a "Redfield ratio" for the microbial biomass?, Biogeochemistry, 85, 235-252, https://doi.org/10.1007/s10533-007-9132-0, 2007.

Conrad, R.: Microbial ecology of methanogens and methanotrophs, Adv. Agron., 96, 1-63, https://doi.org/10.1016/S00652113(07)96005-8, 2007.

Del Grosso, S. J., Parton, W. J., Mosier, A. R., Ojima, D. S., Potter, C. S., Borken, W., Brumme, R., Butterbach-Bahl, K., Crill, P. M., Dobbie, K., and Smith, K. A.: General $\mathrm{CH}_{4}$ oxidation model and comparisons of $\mathrm{CH}_{4}$ oxidation in natural and managed systems, Global Biogeochem. Cy., 14, 999-1019, https://doi.org/10.1029/1999GB001226, 2000.

Evans, S. E. and Wallenstein, M. D.: Soil microbial community response to drying and rewetting stress: does historical precipitation regime matter?, Biogeochemistry, 109, 101-116, https://doi.org/10.1007/s10533-011-9638-3, 2012.

Fraser, L. H., Henry, H. A. L., Carlyle, C. N., White, S. R., Beierkuhnlein, C., Cahill Jr., J. F., Casper, B. B., Cleland, E., Collins, S. L., Dukes, J. S., Knapp, A. K., Lind, E., Long, R., Luo, Y., Reich, P. B., Smith, M. D., Sternberg, M., and Turkington, R.: Coordinated distributed experiments: an emerging tool for testing global hypotheses in ecology 
and environmental science, Front. Ecol. Environ., 11, 147-155, https://doi.org/10.1890/110279, 2013.

Frei, C., Schöll, R., Fukutome, S., Schmidli, J., and Vidale, P. L.: Future change of precipitation extremes in Europe: Intercomparison of scenarios from regional climate models, J. Geophys. Res.Atmos., 111, D06105, https://doi.org/10.1029/2005JD005965, 2006.

Goldstein, A. H., Hultman, N. E., Fracheboud, J. M., Bauer, M. R., Panek, J. A., Xu, M., Qi, Y., Guenther, A. B., and Baugh, W.: Effects of climate variability on the carbon dioxide, water, and sensible heat fluxes above a ponderosa pine plantation in the Sierra Nevada (CA), Agr. Forest Meteorol., 101, 113-129, https://doi.org/10.1016/S0168-1923(99)00168-9, 2000.

Granier, A., Reichstein, M., Bréda, N., Janssens, I. A., Falge, E., Ciais, P., Grünwald, T., Aubinet, M., Berbigier, P., Bernhofer, C., Buchmann, N., Facini, O., Grassi, G., Heinesch, B., Ilvesniemi, H., Keronen, P., Knohl, A., Köstner, B., Lagergren, F., Lindroth, A., Longdoz, B., Loustau, D., Mateus, J., Montagnani, L., Nys, C., Moors, E., Papale, D., Peiffer, M., Pilegaard, K., Pita, G., Pumpanen, J., Rambal, S., Rebmann, C., Rodrigues, A., Seufert, G., Tenhunen, J., Vesala, T., and Wang, Q.: Evidence for soil water control on carbon and water dynamics in European forests during the extremely dry year: 2003, Agr. Forest Meteorol., 143, 123-145, https://doi.org/10.1016/j.agrformet.2006.12.004, 2007.

Halbritter, A. H., De Boeck, H. J., Eycott, A. E., Reinsch, S., Robinson, D. A., Vicca, S., Berauer, B., Christiansen, C. T., Estiarte, M., Grünzweig, J. M., Gya, R., Hansen, K., Jentsch, A., Lee, H., Linder, S., Marshall, J., Peñuelas, J., Schmidt, I. K., StuartHaëntjens, E., Wilfahrt, P., and the ClimMani Working Group, Vandvik, V.: The handbook for standardized field and laboratory measurements in terrestrial climate change experiments and observational studies (ClimEx), Methods Ecol. Evol., 11, 22-37, https://doi.org/10.1111/2041-210X.13331, 2020.

Hasibeder, R., Fuchslueger, L., Richter, A., and Bahn, M.: Summer drought alters carbon allocation to roots and root respiration in mountain grassland, New Phytol., 205, 1117-1127, https://doi.org/10.1111/nph.13146, 2015.

He, M, and Dijkstra, F. A.: Drought effect on plant nitrogen and phosphorus: a meta-analysis, New Phytol., 204, 924-931, https://doi.org/10.1111/nph.12952, 2014.

He, Y., Yang, J., Zhuang, Q., Harden, J. W., McGuire, A. D., Liu, Y., Wang, G., and Gu, L.: Incorporating microbial dormancy dynamics into soil decomposition models to improve quantification of soil carbon dynamics of northern temperate forests, J. Geophys. Res.-Biogeo., 120, 2596-2611, https://doi.org/10.1002/2015JG003130, 2015.

Hedges, L. V., Gurevitch, J., and Curtis, P. S.: The metaanalysis of response ratios in experimental ecology, Ecology, 80, 1150-1156, https://doi.org/10.1890/00129658(1999)080[1150:TMAORR]2.0.CO;2, 1999.

Heisler-White, J. L., Knapp, A. K., and Kelly, E. F.: Increasing precipitation event size increases aboveground net primary productivity in a semi-arid grassland, Oecologia, 158, 129-140, https://doi.org/10.1007/s00442-008-1116-9, 2008.

Hilton, T. W., Loik, M. E., and Campbell, J. E.: Simulating International Drought Experiment field observations using the Community Land Model, Agr. Forest Meteorol., 266-267, 173-183, https://doi.org/10.1016/j.agrformet.2018.12.016, 2019.
Homyak, P. M., Allison, S. D., Huxman, T. E., Goulden, M. L., and Treseder, K. K.: Effects of drought manipulation on soil nitrogen cycling: a meta-analysis, J. Geophys. Res-Biogeo., 122, 3260 3272, https://doi.org/10.1002/2017JG004146, 2017.

Hu, R., Wang, X., Pan, Y., Zhang, Y., and Zhang, H.: The response mechanisms of soil $\mathrm{N}$ mineralization under biological soil crusts to temperature and moisture in temperate desert regions, Eur. J. Soil Biol., 62, 66-73, https://doi.org/10.1016/j.ejsobi.2014.02.008, 2014.

Hueso, S., García, C., and Hernández, T.: Severe drought conditions modify the microbial community structure, size and activity in amended and unamended soils, Soil Biol. Biochem., 50, 167173, https://doi.org/10.1016/j.soilbio.2012.03.026, 2012.

Hume, D. J., Criswell, J. G., and Stevenson, K. R.: Effects of soil moisture around nodules on nitrogen fixation by well watered soybeans, Can. J. Plant Sci., 56, 811-815, https://doi.org/10.4141/cjps76-132, 1976.

Huwaldt, J. A. and Steinhorst, S.: Plot Digitizer, available at: http: //plotdigitizer.sourceforge.net/ (last access: 19 August 2017), 2015.

Jensen, K. D., Beier, C., Michelsen, A., and Emmett, B.: Effects of experimental drought on microbial processes in two temperate heathlands at contrasting water conditions, Appl. Soil Ecol., 24, 165-176, https://doi.org/10.1016/S0929-1393(03)00091-X, 2003.

Knapp, A. K., Smith, M. D., Hobbie, S. E., Collins, S. L., Fahey, T. J., Hansen, G. J. A., Landis, D. A., La Pierre, K J., Melillo, J. M., Seastedt, T. R., Shaver, G. R., and Webster, J. R.: Past, present, and future roles of long-term experiments in the LTER network, BioScience, 62, 377-389, https://doi.org/10.1525/bio.2012.62.4.9, 2012.

Knapp, A. K., Avolio, M. L., Carroll, C. J. W., Collins, S. L., Dukes, J. S., Fraser, L. H., Griffin-Nolan, R. J., Hoover, D. L., Jentsch, A., Loik, M. E., Phillips, R. P., Post, A. K., Sala, O. E., Slette, I. J., Yahdjian, L., and Smith, M. D.: Pushing precipitation to the extremes in distributed experiments: recommendations for simulating wet and dry years, Glob. Change Biol., 23, 1774-1782, https://doi.org/10.1111/gcb.13504, 2017.

Kreyling, J. and Beier, C.: Complexity in climate change manipulation experiments, BioScience, 63, 763-767, https://doi.org/10.1525/bio.2013.63.9.12, 2013.

Kreyling, J., Arfin Khan, M. A. S., Sultana, F., Babel, W., Beierkuhnlein, C. Foken, T., Walter, J., and Jentsch, A.: Drought effects in climate change manipulation experiments: quantifying the influence of ambient weather conditions and rain-out shelter artifacts, Ecosystems, 20, 301-315, https://doi.org/10.1007/s10021-016-0025-8, 2017.

Le Mer, J. and Roger, P.: Production, oxidation, emission and consumption of methane by soils: A review, Eur. J. Soil Biol., 37, 25-50, https://doi.org/10.1016/S1164-5563(01)01067-6, 2001.

Lenderink, G. and van Meijgaard, E.: Increase in hourly precipitation extremes beyond expectations from temperature changes, Nat. Geosci., 1, 511-514, https://doi.org/10.1038/ngeo262, 2008.

Lennon, J. T., Aanderud, Z. T., Lehmkuhl, B. K., and Schoolmaster, Jr., D. R.: Mapping the niche space of soil microorganisms using taxonomy and traits, Ecology, 93, 1867-1879, https://doi.org/10.1890/11-1745.1, 2012. 
Liu, L., Wang, X., Lajeunesse, M. J., Miao, G., Piao, S., Wan, S., Wu, Y., Wang, Z., Yang, S., Li, P., and Deng, M.: A cross-biome synthesis of soil respiration and its determinants under simulated precipitation changes, Glob. Change Biol., 22, 1394-1405, https://doi.org/10.1111/gcb.13156, 2016.

Ma, L., Guo, C., Xin, X., Yuan, S., and Wang, R.: Effects of belowground litter addition, increased precipitation and clipping on soil carbon and nitrogen mineralization in a temperate steppe, Biogeosciences, 10, 7361-7372, https://doi.org/10.5194/bg-107361-2013, 2013.

Maire, V., Wright, I. J., Prentice, I. C., Batjes, N. H., Bhaskar, R., van Bodegom, P. M., Cornwell, W. K., Ellsworth, D., Niinemets, Ü., Ordonez, A., Reich, P. B., and Santiago, L. S.: Global effects of soil and climate on leaf photosynthetic traits and rates, Global Ecol. Biogeogr., 24, 706-717, https://doi.org/10.1111/geb.12296, 2015.

Månsson, K. F., Olsson, M. O., Falkengren-Grerup, U., and Bengtsson, G.: Soil moisture variations affect short-term plantmicrobial competition for ammonium, glycine, and glutamate, Ecol. Evol., 4, 1061-1072, https://doi.org/10.1002/ece3.1004, 2014.

Manzoni, S., Schimel, J. P., and Porporato, A.: Responses of soil microbial communities to water stress: results from a meta-analysis, Ecology, 93, 930-938, https://doi.org/10.1890/11-0026.1, 2012.

Manzoni, S., Moyano, F., Kätterer, T., and Schimel, J.: Modeling coupled enzymatic and solute transport controls on decomposition in drying soils, Soil Biol. Biochem., 95, 275-287, https://doi.org/10.1016/j.soilbio.2016.01.006, 2016.

Mariotte, P., Canarini, A., and Dijkstra, F. A.: Stoichiometric N:P flexibility and mycorrhizal symbiosis favour plant resistance against drought, J. Ecol., 105, 958-967, https://doi.org/10.1111/1365-2745.12731, 2017.

Matías, L., Castro, J., and Zamora, R.: Soil-nutrient availability under a global-change scenario in a Mediterranean mountain ecosystem, Glob. Change Biol., 17, 1646-1657, https://doi.org/10.1111/j.1365-2486.2010.02338.x, 2011.

Mazzarino, M. J., Bertiller, M. B., Sain, C., Satti, P., and Coronato, F.: Soil nitrogen dynamics in northeastern Patagonia steppe under different precipitation regimes, Plant Soil, 202, 125-131, https://doi.org/10.1023/A:1004389011473, 1998.

Niboyet, A., Le Roux, X., Dijkstra, P., Hungate, B. A., Barthes, L., Blankinship, J. C., Brown, J. R., Field, C. B., and Leadley, P. W.: Testing interactive effects of global environmental changes on soil nitrogen cycling, Ecosphere, 2, 1-24, https://doi.org/10.1890/ES10-00148.1, 2011.

Pilbeam, C. J., Mahapatra, B. S., and Wood, M.: Soil matric potential effects on gross rates of nitrogen mineralization in an orthic ferralsol from Kenya, Soil Biol. Biochem., 25, 1409-1413, https://doi.org/10.1016/0038-0717(93)90055-G, 1993.

Placella, S. A., Brodie, E. L., and Firestone, M. K.: Rainfallinduced carbon dioxide pulses result from sequential resuscitation of phylogenetically clustered microbial groups, P. Natl. Acad. Sci. USA, 109, 10931-10936, https://doi.org/10.1073/pnas.1204306109, 2012.

Redfield, A. C.: The biological control of chemical factors in the environment, Am. Sci., 46, 205-221, 1958.

Reinsch, S., Koller, E., Sowerby, A., de Dato, G., Estiarte, M., Guidolotti, G., Kovács-Láng, E., Kröel-Dulay, G., Lellei-Kovács, E., Larsen, K. S., Liberati, D., Peñuelas, J., Ransijn, J., Robin- son, D. A., Schmidt, I. K., Smith, A. R., Tietema, A., Dukes, J. S., Beier, C., and Emmett, B. A.: Shrubland primary production and soil respiration diverge along European climate gradient, Sci. Rep.-UK, 7, 43952, https://doi.org/10.1038/srep43952, 2017.

Ren, C., Chen, J., Lu, X., Doughty, R., Zhao, F., Zhong, Z., Han, X., Yang, G., Feng, Y., and Ren, G.: Responses of soil total microbial biomass and community compositions to rainfall reductions, Soil Biol. Biochem., 116, 4-10, https://doi.org/10.1016/j.soilbio.2017.09.028, 2018.

Ren, C., Zhao, F., Shi, Z., Chen, J., Han, X., Yang, G., Feng, Y., and Ren, G.: Differential responses of soil microbial biomass and carbon-degrading enzyme activities to altered precipitation, Soil Biol. Biochem., 115, 1-10, https://doi.org/10.1016/j.soilbio.2017.08.002, 2017.

Salazar, A., Sulman, B. N., and Dukes, J. S.: Microbial dormancy promotes microbial biomass and respiration across pulses of drying-wetting stress, Soil Biol. Biochem., 116, 237-244, https://doi.org/10.1016/j.soilbio.2017.10.017, 2018.

Salazar, A., Lennon, J. T., and Dukes, J. S.: Microbial dormancy improves predictability of soil respiration at the seasonal time scale, Biogeochemistry, 144, 103-116, https://doi.org/10.1007/s10533019-00574-5, 2019.

Salazar-Villegas, A., Blagodatskaya, E., and Dukes, J. S.: Changes in the size of the active microbial pool explain short-term soil respiratory responses to temperature and moisture, Front. Microbiol., 7, Article 524, https://doi.org/10.3389/fmicb.2016.00524, 2016.

Sardans, J. and Peñuelas, J.: Drought decreases soil enzyme activity in a Mediterranean Quercus ilex L. forest, Soil Biol. Biochem., 37, 455-461, https://doi.org/10.1016/j.soilbio.2004.08.004, 2005.

Sardans, J., Rivas-Ubach, A., and Peñuelas, J.: The C:N:P stoichiometry of organisms and ecosystems in a changing world: A review and perspectives, Perspect. Plant. Ecol., 14, 33-47, https://doi.org/10.1016/j.ppees.2011.08.002, 2012.

Schaeffer, S. M., Sharp, E., Schimel, J. P., and Welker, J. M.: Soil-plant $\mathrm{N}$ processes in a High Arctic ecosystem, NW Greenland are altered by long-term experimental warming and higher rainfall, Glob. Change Biol., 19, 3529-3539, https://doi.org/10.1111/gcb.12318, 2013.

Schimel, J. P.: Life in dry soils: Effects of drought on soil microbial communities and processes, Annu. Rev. Ecol. Evol. S., 49, 409-432, https://doi.org/10.1146/annurev-ecolsys-110617062614, 2018.

Schimel, J., Balser, T. C., and Wallenstein, M.: Microbial stressresponse physiology and its implications for ecosystem function, Ecology, 88, 1386-1394, https://doi.org/10.1890/06-0219, 2007.

Sierra, J.: Temperature and soil moisture dependence of N mineralization in intact soil cores, Soil Biol. Biochem., 29, 1557-1563, https://doi.org/10.1016/S0038-0717(96)00288-X, 1997.

Skopp, J., Jawson, M. D., and Doran, J. W.: Steady-state aerobic microbial activity as a function of soil water content, Soil Sci. Soc. Am. J., 54, 1619-1625, https://doi.org/10.2136/sssaj1990.03615995005400060018x, 1990.

Song, J., Wan, S., Piao, S., Knapp, A. K., Classen, A. T., Vicca, S., Ciais, P., Hovenden, M. J., Leuzinger, S., Beier, C., Kardol, P., Xia, J., Liu, Q., Ru, J., Zhou, Z., Luo, Y., Guo, D., Langley, J. A., Zscheischler, J., Dukes, J. S., Tang, J., Chen, J., Hofmockel, K. 
S., Kueppers, L. M., Rustad, L., Liu, L., Smith, M. D., Templer, P. H., Thomas, R. Q., Norby, R. J., Phillips, R. P., Niu, S., Fatichi, S., Wang, Y., Shao, P., Han, H., Wang, D., Lei, L., Wang, J., Li, X., Zhang, Q., Li, X., Su, F., Liu, B., Yang, F., Ma, G., Li, G., Liu, Y., Liu, Y., Yang, Z., Zhang, K., Miao, Y., Hu, M., Yan, C., Zhang, A., Zhong, M., Hui, Y., Li, Y., and Zheng, M.: A metaanalysis of 1,119 manipulative experiments on terrestrial carboncycling responses to global change, Nat. Ecol. Evol., 3, 13091320, https://doi.org/10.1038/s41559-019-0958-3, 2019.

Stark, J. M. and Firestone, M. K.: Mechanisms for soil moisture effects on activity of nitrifying bacteria, Appl. Environ. Microb., 61, 218-221, 1995.

Streeter, J. G.: Effects of drought on nitrogen fixation in soybean root nodules, Plant Cell Environ., 26, 1199-1204, https://doi.org/10.1046/j.1365-3040.2003.01041.x, 2003.

Tecon, R. and Or, D.: Biophysical processes supporting the diversity of microbial life in soil, FEMS Microbiol. Rev., 41, 599-623, https://doi.org/10.1093/femsre/fux039, 2017.

Van Meeteren, M. J. M., Tietema, A., and Westerveld, J. W.: Regulation of microbial carbon, nitrogen, and phosphorus transformations by temperature and moisture during decomposition of Calluna vulgaris litter, Biol. Fert. Soils, 44, 103-112, https://doi.org/10.1007/s00374-007-0184-z, 2007.

Vicca, S., Bahn, M., Estiarte, M., van Loon, E. E., Vargas, R., Alberti, G., Ambus, P., Arain, M. A., Beier, C., Bentley, L. P., Borken, W., Buchmann, N., Collins, S. L., de Dato, G., Dukes, J. S., Escolar, C., Fay, P., Guidolotti, G., Hanson, P. J., Kahmen, A., Kröel-Dulay, G., Ladreiter-Knauss, T., Larsen, K. S., LelleiKovacs, E., Lebrija-Trejos, E., Maestre, F. T., Marhan, S., Marshall, M., Meir, P., Miao, Y., Muhr, J., Niklaus, P. A., Ogaya, R., Peñuelas, J., Poll, C., Rustad, L. E., Savage, K., Schindlbacher, A., Schmidt, I. K., Smith, A. R., Sotta, E. D., Suseela, V., Tietema, A., van Gestel, N., van Straaten, O., Wan, S., Weber, U., and Janssens, I. A.: Can current moisture responses predict soil $\mathrm{CO}_{2}$ efflux under altered precipitation regimes? A synthesis of manipulation experiments, Biogeosciences, 11, 2991-3013, https://doi.org/10.5194/bg-11-2991-2014, 2014.

Wang, G., Jagadamma, S., Mayes, M. A., Schadt, C. W., Steinweg, J. M., Gu, L., and Post, W. M.: Microbial dormancy improves development and experimental validation of ecosystem model, ISME J., 9, 226-237, https://doi.org/10.1038/ismej.2014.120, 2015.

Weier, K. L., Doran, J. W., Power, J. F., and Walters, D. T.: Denitrification and the dinitrogen/nitrous oxide ratio as affected by soil water, available carbon, and nitrate, Soil Sci. Soc. Am. J., 57, 6672, https://doi.org/10.2136/sssaj1993.03615995005700010013x, 1993.

Wu, Z., Dijkstra, P., Koch, G. W., Peñuelas, J., and Hungate, B. A.: Responses of terrestrial ecosystems to temperature and precipitation change: a meta-analysis of experimental manipulation, Glob. Change Biol., 17, 927-942, https://doi.org/10.1111/j.13652486.2010.02302.x, 2011.

Xiao, W., Chen, X., Jing, X., and Zhu, B.: A metaanalysis of soil extracellular enzyme activities in response to global change, Soil Biol. Biochem., 123, 21-32, https://doi.org/10.1016/j.soilbio.2018.05.001, 2018.
Yan, G., Mu, C., Xing, Y., and Wang, Q.: Responses and mechanisms of soil greenhouse gas fluxes to changes in precipitation intensity and duration: a meta-analysis for a global perspective, Can. J. Soil Sci., 98, 591-603, https://doi.org/10.1139/cjss-20180002, 2018.

Yuan, Z. Y. and Chen, H. Y. H.: Decoupling of nitrogen and phosphorus in terrestrial plants associated with global changes, Nat. Clim. Change, 5, 465-469, https://doi.org/10.1038/nclimate2549, 2015.

Yuan, Z. Y., Jiao, F., Shi, X. R., Sardans, J., Maestre, F. T., Delgado-Baquerizo, M., Reich, P. B., and Peñuelas, J.: Experimental and observational studies find contrasting responses of soil nutrients to climate change, eLife, 6, e23255, https://doi.org/10.7554/eLife.23255, 2017.

Yue, K., Peng, Y., Fornara, D. A., Van Meerbeek, K., Vesterdal, L., Yang, W., Peng, C., Tan, B., Zhou, W., Xu, Z., Ni, X., Zhang, L., Wu, F., and Svenning, J.: Responses of nitrogen concentrations and pools to multiple environmental change drivers: A metaanalysis across terrestrial ecosystems, Global Ecol. Biogeogr., 28, 690-724, https://doi.org/10.1111/geb.12884, 2019.

Yue, K., Yang, W., Peng, Y., Peng, C., Tan, B., Xu, Z., Zhang, L., Ni, X., Zhou, W., and Wu, F.: Individual and combined effects of multiple global change drivers on terrestrial phosphorus pools: A meta-analysis, Sci. Total Environ., 630, 181-188, https://doi.org/10.1016/j.scitotenv.2018.02.213, 2018.

Yuste, J. C., Peñuelas, J., Estiarte, M., Garcia-Mas, J., Mattana, S., Ogaya, R., Pujol, M., and Sardans, J.: Drought-resistant fungi control soil organic matter decomposition and its response to temperature, Glob. Change Biol., 17, 1475-1486, https://doi.org/10.1111/j.1365-2486.2010.02300.x, 2011.

Zhang, N., Liu, W., Yang, H., Yu, X., Gutknecht, J. L. M., Zhang, Z., Wan, S., and Ma, K.: Soil microbial responses to warming and increased precipitation and their implications for ecosystem C cycling, Oecologia, 173, 1125-1142, https://doi.org/10.1007/s00442-013-2685-9, 2013.

Zhao, C., Miao, Y., Yu, C., Zhu, L., Wang, F., Jiang, L., Hui, D., and Wan, S.: Soil microbial community composition and respiration along an experimental precipitation gradient in a semiarid steppe, Sci. Rep.-UK, 6, 24317, https://doi.org/10.1038/srep24317, 2016.

Zhou, X., Chen, C., Wang, Y., Xu, Z., Han, H., Li, L., and Wan, S.: Warming and increased precipitation have differential effects on soil extracellular enzyme activities in a temperate grassland, Sci. Total Environ., 444, 552-558, https://doi.org/10.1016/j.scitotenv.2012.12.023, 2013.

Zhou, X., Zhou, L., Nie, Y., Fu, Y., Du, Z., Shao, J., Zheng, Z., and Wang, X.: Similar responses of soil carbon storage to drought and irrigation in terrestrial ecosystems but with contrasting mechanisms: A meta-analysis, Agr. Ecosyst. Environ., 228, 70-81, https://doi.org/10.1016/j.agee.2016.04.030, 2016.

Zhou, Z., Wang, C., and Luo, Y.: Response of soil microbial communities to altered precipitation: A global synthesis, Global Ecol Biogeogr., 27, 1121-1136, https://doi.org/10.1111/geb.12761, 2018. 